\title{
Morphometric analysis of Vaitarna and Ulhas river basins, Maharashtra, India: using geospatial techniques
}

\author{
Sumit Das ${ }^{1} \mathbb{( 1 0} \cdot$ Sudhakar D. Pardeshi ${ }^{1}$
}

Received: 28 May 2017 / Accepted: 10 September 2018 / Published online: 18 September 2018

(c) The Author(s) 2018

\begin{abstract}
Drainage network quantification with respect to the climate, tectonics, lithology and geomorphology provides significant evidence of the drainage development, hydro-geomorphic and denudation characteristics of an area. The present study was carried out by using Shuttle Radar Topographic Mission DEM to study the drainage morphometry and its influence on the hydrological characteristics of Vaitarna and Ulhas basins in Maharashtra, India. Results of the morphometric analysis reveal that the catchment of Vaitarna and Ulhas can be described as of 6th and 7th order drainage basins, encompassing an area of 3795 and $4733 \mathrm{~km}^{2}$, respectively. Additionally, Vaitarna basin is characterised by relatively higher mean bifurcation ratio as compared to the Ulhas basin, indicative of higher structural control and steeper gradient in Vaitarna basin. Lower drainage density and stream frequency affirm availability of permeable sub-surface material and homogeneous lithological characteristics in both basins. The shape parameters show both basins are semicircular with dendritic and sub-dendritic drainage pattern. The relief parameters of Vaitarna and Ulhas suggest both of these basins are characterised by very high relief and steep slope. GIS-based analysis of all these morphometric parameters indicates the drainage development of the study area progressed well beyond maturity stage and lithology have a major impact on the drainage development in Vaitarna and Ulhas basins.
\end{abstract}

Keywords Morphometric analysis $\cdot$ Western Ghats $\cdot$ Watershed management $\cdot$ Geospatial technique $\cdot$ Maharashtra $\cdot$ India

\section{Introduction}

Development of a drainage system through geologic past depends on several factors such as climate, lithology, tectonics and geomorphic controls of an area. Geomorphometry is the measurement and mathematical investigation of the earth's surface, dimension and its landforms (Clarke 1996). The morphometric parameters can be derived by measuring the linear, aerial and relief properties along with slope of the basin (Nautiyal 1994; Nag and Chakraborty 2003; Magesh et al. 2012).

Since now many workers carried out morphometric analysis to determine the drainage network and basin characteristics of drainage development (Miller 1953; Boulton 1968; Gardiner 1975; Costa 1987; Moussa 2003; Mesa 2006; Magesh et al. 2012), but the pioneer study of morphometric analysis was conducted by Horton $(1932,1945)$, Miller

Sumit Das

sumit.das.earthscience@gmail.com

1 Department of Geography, Savitribai Phule Pune University, Pune 411007, India
(1953) and Strahler (1964). All the works on morphometry performed by recent workers are following their principles. Although many researchers have been carried out the morphometric study, an insufficient number of works describe the relationship of drainage morphometry with respect to the climate, lithology and tectonics of an area (Das et al. 2018).

Seasonal monsoon climate characterises Vaitarna and Ulhas basins in the western Deccan trap region. Both basins show a considerable hydrological variability in the drainage network throughout the year. The study area also experienced a rapid erosion in the recent geological period due to the recession of Western Ghat escarpment (Subrahmanya 1987; Widdowson 1997; Kale and Shejwalkar 2007) through the combined processes of climate, tectonics, lithology and slope. These factors play a crucial role in landscape evolution (Goodbred 2003; Zhang 2005) and leave fingerprints on the drainage network (Das et al. 2018). Assessment of these factors together with drainage network and relief characteristics divulges the hydrological, geomorphic and denudation history of an area.

In this work, through the assessment of drainage network and relief parameters together with climate, tectonics and lithology an attempt has been made to understand the present 
hydro-geomorphic characteristics and the stage of drainage basin development of Vaitarna and Ulhas basins, Maharashtra. This morphometric technique is an important and powerful method for watershed management, groundwater supervision, demarcation of groundwater potential zones, pedological assessment, environmental and ecological evaluation.

\section{Study area}

Vaitarna and Ulhas rivers are originating from the greatest escarpment of India (Western Ghats) and flowing through the Konkan region to the Arabian Sea. These river basins are laying into the Maharashtra State, India (Fig. 1). Latitudinal and longitudinal extension of the study area is $18^{\circ} 45^{\prime} \mathrm{N}-20^{\circ}$ $\mathrm{N}$ and $72^{\circ} 45^{\prime} \mathrm{E}-74^{\circ} \mathrm{E}$. Total area of Vaitarna and Ulhas basins are 3795 and $4733 \mathrm{~km}^{2}$, respectively. A large part of the study area is covering dispersed vegetation. Upstream area of Vaitarna and Ulhas basins has a very steep slope. Mostly, dendritic drainage pattern has been observed in both basins, but rectangular drainage pattern characterises some areas due to the influence of faults available in these watersheds. The study area is having several numbers of water reservoir such as lakes, dams, etc. A major part of the area is covering isolated hills (elevation $<500 \mathrm{~m}$ ), and the topographical slope is towards west. The area is characterised by numerous joints, dykes and fractures along the NNE-SSW direction (Das 2017; Das and Pardeshi 2018). The study area can be divided into three major geomorphic parts which are steep escarpment from where the streams are originating, the pediment on the central part of the basins and the coastal lowland area. Major rock type of the study area is basalt, formed due to the Deccan basalt flooding by Reunion hotspot in the Cretaceous-Tertiary period. In lower reaches, both of these basins show a large area of alluvium deposition (Fig. 2).

The study area is located in monsoon climatic region where rainfall can only be seen in monsoon months (JuneSept), rest of the times the region shows dry climatic condition (Doke et al. 2018). Although the region remains dry during the non-monsoon period still, the area is having mean

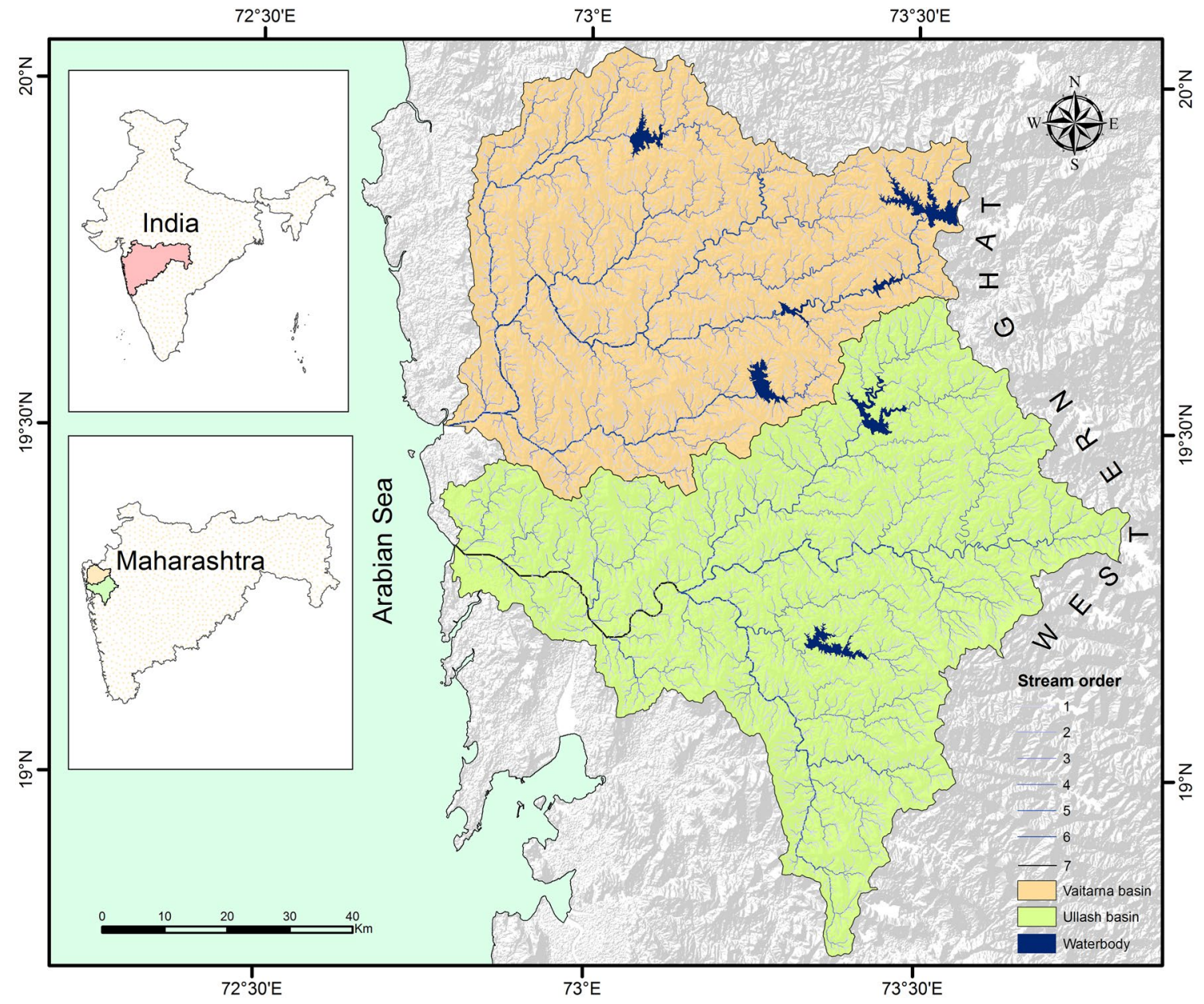

Fig. 1 Location map of the study area with respect to Maharashtra State and India 


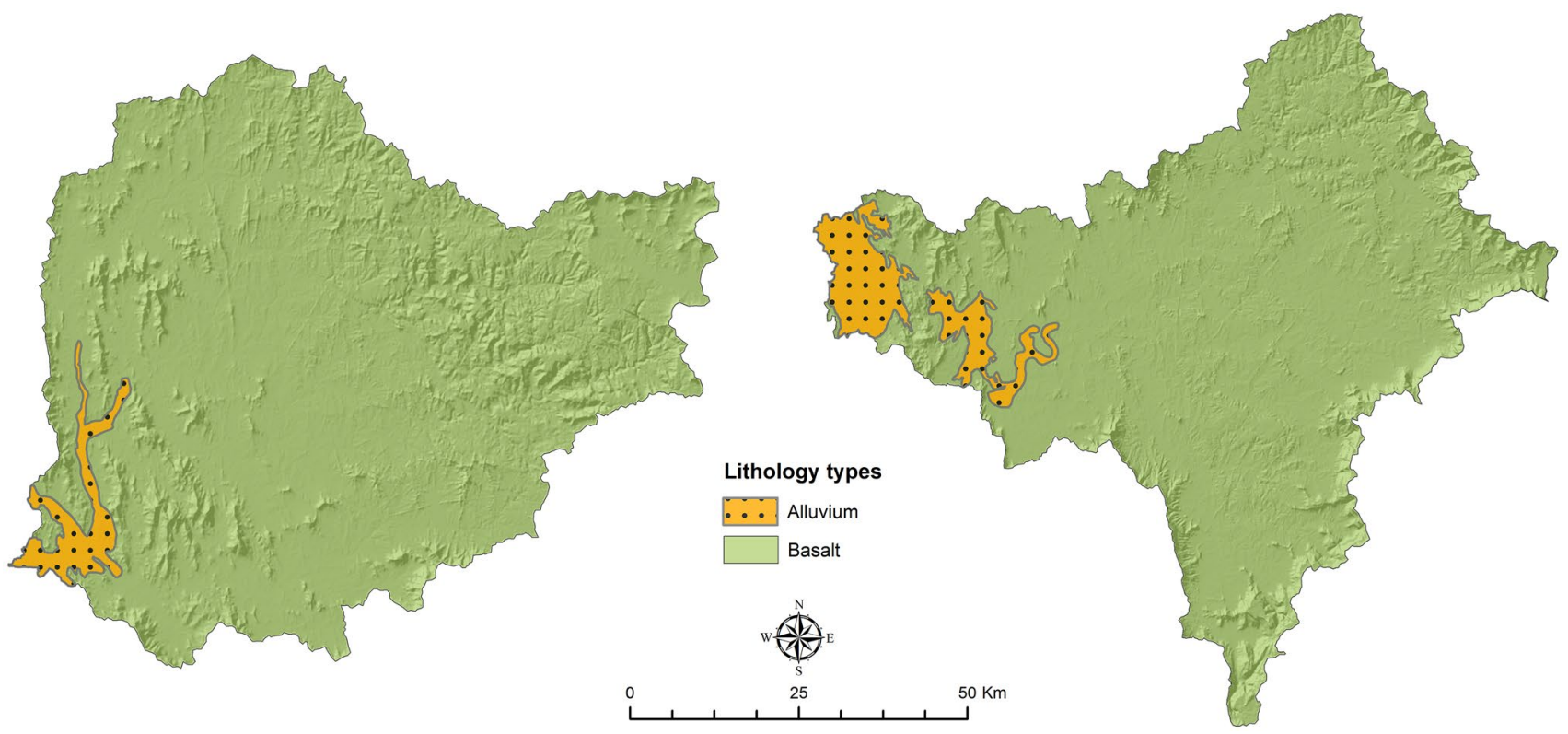

Fig. 2 Maps are showing lithological characteristics of Vaitarna and Ulhas basin

annual rainfall more than $2500 \mathrm{~mm}$. The temperature of the study area varies between 15 and $35^{\circ} \mathrm{C}$. Elevation of the study area ranges from 0 metres in coastal lowland region to 1400 metres above sea level at the escarpment zone. All these parameters of physical environment greatly affect the drainage morphometry of both these rivers.

\section{Methodology}

Earlier morphometric measurements were carried out by using traditional methods such as topographical maps and field analysis. In late twentieth century, advancement of technology introduced remote sensing and GIS, by which analysis of morphometric data for large drainage basin area became much easier than before (Das and Pardeshi 2018). Nowadays, for the study of morphometric properties and basin characteristics, remote sensing data such as Digital Elevation Model (DEM) has become very popular worldwide. In recent years, numerous studies on morphometric analysis have been carried out all over the world by using DEM and GIS (Dietrich et al. 1993; Nag 1998; Lindsay et al. 2004; Deng 2007; Lindsay and Evans 2008; Wilson et al. 2008; Verstappen 1983; Chopra et al. 2005; Mesa 2006; Magesh et al. 2012; Jacques et al. 2014). All the morphometric parameters can be automatically calculated by using DEM in GIS software, and the output data can be utilised for further geoenvironmental assessment (Das et al. 2018).

In this study, Shuttle Radar Topographic Mission (SRTM) data sets with 3 arc-sec $(90 \mathrm{~m})$ resolution used in ArcGIS environment to delineate the drainage basins. SRTM data is freely obtainable at http://srtm.csi.cgiar.org, and the data covers almost entire earth $\left(60^{\circ} \mathrm{N}-60^{\circ} \mathrm{S}\right)$ with $5^{\circ} \times 5^{\circ}$ tiles. The processing of SRTM data is very first and inexpensive way for regional topographical analysis with satisfactory accuracy.

Figure 3 shows the methodology which has been followed in this study to generate streams. SRTM data were filled in ArcGIS environment to correct DEM errors. Flow direction, flow accumulation and stream order tools were used to generate streams followed by the Strahler's method of stream ordering (1952). All the rivers with no tributary marked as 1st order stream; two 1 st order streams join and form 2 nd order stream and so on. The highest drainage order found in Vaitarna and Ulhas basins are 6th and 7th order, respectively. Later, all the morphometric parameters such as basin area, basin perimeter, stream length, bifurcation ratio, drainage density, stream frequency, relief, relief ratio, circularity ratio, elongation ratio, form factor, etc. were calculated to evaluate the basin characteristics and the stage of drainage development. Table 1 shows the list of morphometric parameters and appropriate formulae which are used in this study.

\section{Results}

Vaitarna and Ulhas river basins have been investigated in this paper are draining about 3795 and $4733 \mathrm{~km}^{2}$ area, respectively. Few factors that control the drainage development are climate, geology and relief. The type of drainage pattern has been observed in both channels are mainly dendritic and sub-dendritic which are an irregular branching of tributaries from many directions joining to the trunk

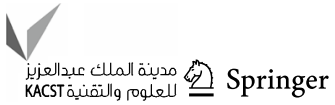




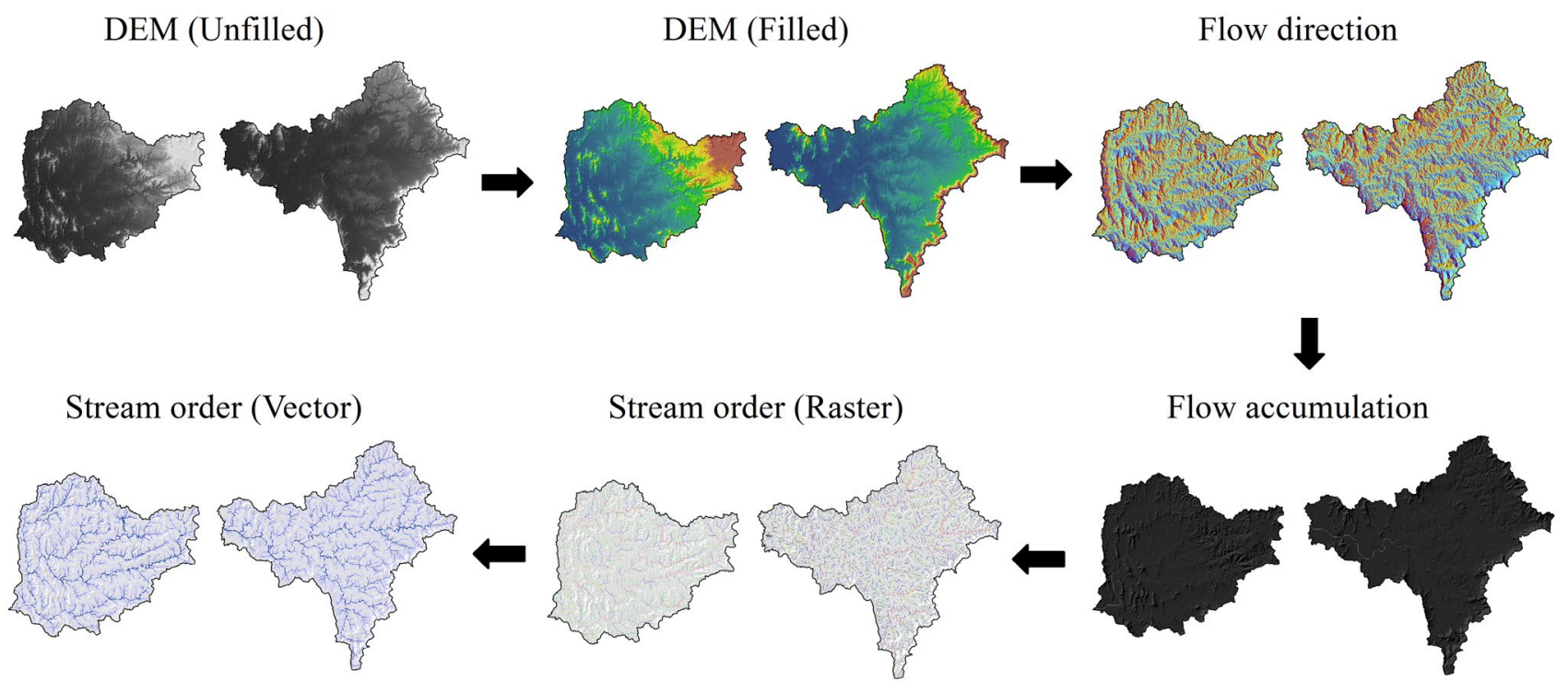

Fig. 3 Methodology carried out to generate the drainage network

Table 1 Morphometric parameters along with corresponding formulae

\begin{tabular}{|c|c|c|c|}
\hline S. no. & Parameters & Formulae & References \\
\hline 1 & Stream order $(\mathrm{u})$ & Hierarchical rank & Strahler (1964) \\
\hline 2 & Stream number $(\mathrm{Nu})$ & Number of streams in each order & Horton (1945) \\
\hline 3 & Stream length $(\mathrm{Lu})$ & Length of stream & Horton (1945) \\
\hline 4 & Mean stream length (Lsm) & $\mathrm{Lsm}=\mathrm{Lu} / \mathrm{Nu}$ & Strahler (1964) \\
\hline 5 & Stream length ratio (RL) & $\mathrm{RL}=\mathrm{Lu} /(\mathrm{Lu}-1)$ & Horton (1945) \\
\hline 6 & Bifurcation ratio $(\mathrm{Rb})$ & $\mathrm{Rb}=\mathrm{Nu} /(\mathrm{Nu}+1)$ & Schumm (1956) \\
\hline 7 & Mean bifurcation ratio (Rbm) & $\mathrm{Rbm}=$ average bifurcation ratio of all order & Strahler (1957) \\
\hline 8 & Drainage density (Dd) & $\mathrm{Dd}=\mathrm{Lu} / \mathrm{A}$ & Horton (1945) \\
\hline 9 & Stream frequency $(\mathrm{Sf})$ & $\mathrm{Sf}=\mathrm{Nu} / \mathrm{A}$ & Horton (1945) \\
\hline 10 & Drainage texture $(\mathrm{T})$ & $\mathrm{T}=\mathrm{Dd} \times \mathrm{Sf}$ & Smith (1950) \\
\hline 11 & Circularity ratio $(\mathrm{Rc})$ & $\mathrm{Rc}=4 \pi \mathrm{A} / \mathrm{P}^{2}$ & Strahler (1964) \\
\hline 12 & Elongation ratio $(\mathrm{Re})$ & $\mathrm{Re}=\mathrm{D} / \mathrm{L}=1.128 \sqrt{\mathrm{A}} / \mathrm{L}$ & Schumm (1956) \\
\hline 13 & Form factor $(\mathrm{Ff})$ & $\mathrm{Ff}=\mathrm{A} / \mathrm{L}^{2}$ & Horton (1945) \\
\hline 14 & Relief (R) & $\mathrm{R}=\mathrm{H}-\mathrm{h}$ & Hadley and Schumm (1961) \\
\hline 15 & Relief ratio (Rh) & $\mathrm{Rh}=\mathrm{R} / \mathrm{L}$ & Schumm (1963) \\
\hline
\end{tabular}

stream at less than of a right angle. Vaitarna and Ulhas have been classified as 6 th and 7 th order basins. Depending on stream network and basin properties, all the morphometric parameters have been calculated to understand hydrological characteristics of both river basins.

\section{Stream order (u)}

Horton (1932) introduced the concept of stream order. To classify the streams in a drainage basin, stream ordering is the most popular method used worldwide. The main stream in the down reach of a basin generally shows the highest stream order. In this study, streams are classified by using Strahler's method of stream ordering. It is observed that Ulhas and Vaitarna have 6th and 7th as highest stream order. The maximum frequency of streams found in 1st order on the hilly rugged terrain. Observation also shows that as stream order increases, the number of streams decreases significantly in both basins (Fig. 4a).

\section{Mean stream length (Lsm)}

Mean stream length (Lsm) represents the characteristics of stream network in the basin surface area. Lsm has been 

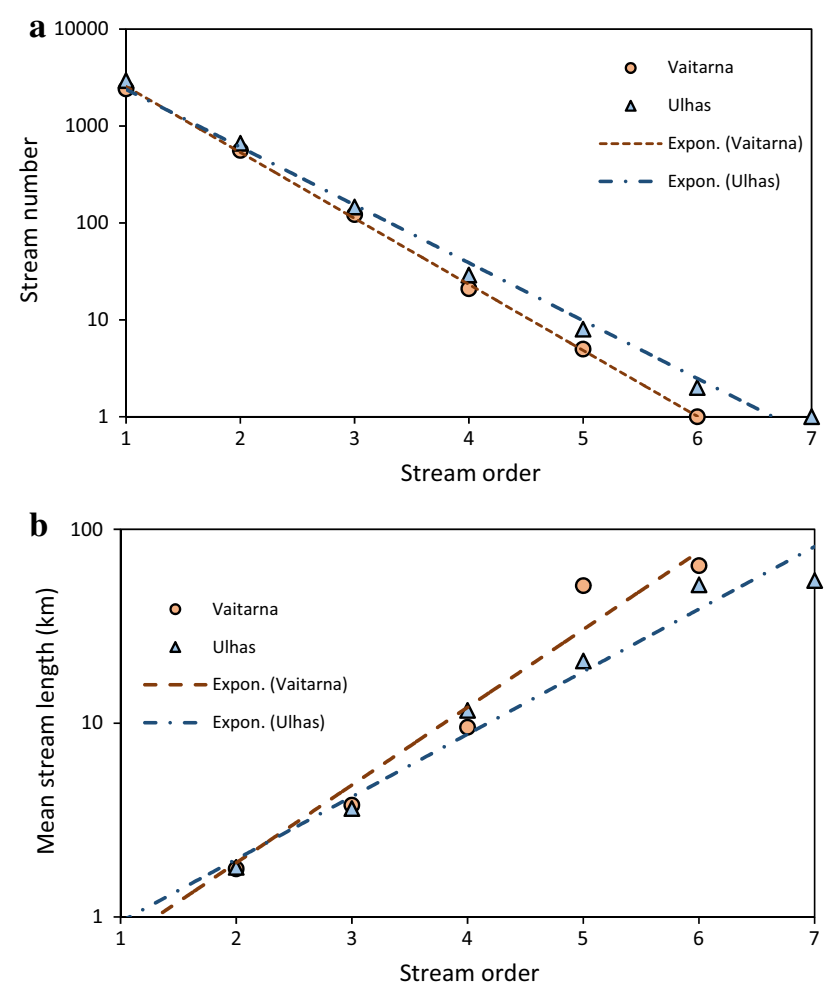

Fig. 4 a Scatterplot is showing the relationship between stream order and stream number. $\mathbf{b}$ The relationship between stream order and mean stream length

calculated by dividing total length of the stream in an order to the total number of stream of the same order. Table 2 indicates the variation of Lsm of Vaitarna and Ulhas basins ranging from 0.91 to $64.98 \mathrm{~km}$ and 0.89 to $54.48 \mathrm{~km}$, respectively. Figure $4 \mathrm{~b}$ illustrates that in a given order, Lsm increases exponentially than the previous lower order. It indicates the trunk stream of an order is comparatively longer than its previous tributary streams.

\section{Stream length ratio (RL)}

Stream length ratio (RL) can be defined as the ratio of the mean length of the one order to the next order of streams (Horton 1945). Table 2 shows some minor variation of RL over the studied river basins. This variation may be occurred due to the different slope and lithological changes in the basin topography. Critical inspection shows increasing trend of stream length ratio from lower order to the higher order in both basins; it implies matured topographical condition.

\section{Bifurcation ratio $(\mathbf{R b})$}

Bifurcation ratio $(\mathrm{Rb})$ can be defined as the ratio of the number of streams in an order to the number of streams in the higher order in the drainage basin (Schumm 1956). Bifurcation ratio shows low values for all basins except where geological structure dominates. Therefore, by computing bifurcation ratio, geological and structural control of the drainage basin can be easily understood. Bifurcation ratio more than 5 indicates significant structural disturbances and the substantial influence of geological structures to the drainage network. The mean bifurcation ratio of Vaitarna and Ulhas are 4.79 and 3.94, respectively. The $R b$ values indicate low to moderate structural control in Vaitarna basin, but Ulhas is not affected by any structural disturbances over drainage network.

Table 2 Results of drainage network properties in Vaitarna and Ulhas basins

\begin{tabular}{|c|c|c|c|c|c|c|c|}
\hline Basin name & $\begin{array}{l}\text { Stream order } \\
\text { (u) }\end{array}$ & $\begin{array}{l}\text { Stream number } \\
(\mathrm{Nu})\end{array}$ & $\begin{array}{l}\text { Stream length } \\
(\mathrm{Lu})(\mathrm{km})\end{array}$ & $\begin{array}{l}\text { Mean stream length } \\
(\mathrm{Lsm})(\mathrm{km})\end{array}$ & $\begin{array}{l}\text { Stream length } \\
\text { ratio }(\mathrm{RL})\end{array}$ & $\begin{array}{l}\text { Bifurcation } \\
\text { ratio }(\mathrm{Rb})\end{array}$ & $\begin{array}{l}\text { Mean bifurca- } \\
\text { tion ratio } \\
(\mathrm{Rbm})\end{array}$ \\
\hline \multirow[t]{6}{*}{ Vaitarna } & I & 2423 & 2208 & 0.91 & - & - & 4.79 \\
\hline & II & 561 & 994 & 1.77 & 1.95 & 4.32 & \\
\hline & III & 122 & 461 & 3.78 & 2.13 & 4.60 & \\
\hline & IV & 21 & 200 & 9.53 & 2.52 & 5.81 & \\
\hline & V & 5 & 256 & 51.29 & 5.38 & 4.2 & \\
\hline & VI & 1 & 65 & 64.98 & 1.27 & 5 & \\
\hline \multirow[t]{7}{*}{ Ulhas } & I & 2942 & 2627 & 0.89 & - & - & 3.94 \\
\hline & II & 664 & 1197 & 1.80 & 2.02 & 4.43 & \\
\hline & III & 146 & 529 & 3.63 & 2.01 & 4.55 & \\
\hline & IV & 29 & 337 & 11.63 & 3.21 & 5.03 & \\
\hline & V & 8 & 167 & 20.92 & 1.80 & 3.63 & \\
\hline & VI & 2 & 103 & 51.74 & 2.47 & 4.00 & \\
\hline & VII & 1 & 54 & 54.48 & 1.05 & 2.00 & \\
\hline
\end{tabular}




\section{Drainage density (Dd)}

Drainage density (Dd) of a basin indicates the closeness of spacing of streams (Horton 1932). It can be defined as the ratio between the total length of streams in all order to the basin area. Generally, in low relief region, drainage density shows lower values and in high relief region, drainage density becomes higher (Strahler 1964). Drainage density of Vaitarna and Ulhas basins is 1.10 and $1.06 \mathrm{~km} / \mathrm{km}^{2}$, respectively (Table 3); it indicates that both river basins are consisting homogeneous lithology which is controlling the drainage density. Figure 5 illustrates the variation of drainage density over Vaitarna and Ulhas basin. Observation

Table 3 Results showing variation of basin morphometric properties of Vaitarna and Ulhas basins

\begin{tabular}{llll}
\hline S. no. & Parameters & \multicolumn{2}{l}{ Basin name } \\
\cline { 3 - 4 } & & Vaitarna & Ulhas \\
\hline 1 & Basin area $(\mathrm{A})\left(\mathrm{km}^{2}\right)$ & 3795 & 4733 \\
2 & Basin perimeter $(\mathrm{km})$ & 353 & 498 \\
3 & Basin length $(\mathrm{km})$ & 95 & 111 \\
4 & Drainage density $(\mathrm{Dd})\left(\mathrm{km} / \mathrm{km}^{2}\right)$ & 1.10 & 1.06 \\
5 & Stream frequency $(\mathrm{Sf})\left(\mathrm{No} / \mathrm{km}^{2}\right)$ & 0.82 & 0.80 \\
6 & Drainage texture $(\mathrm{T})$ & 0.91 & 0.85 \\
7 & Circularity ratio $(\mathrm{Rc})$ & 0.38 & 0.24 \\
8 & Elongation ratio $(\mathrm{Re})$ & 0.73 & 0.70 \\
9 & Form factor $(\mathrm{Ff})$ & 0.42 & 0.38 \\
10 & Relief $(\mathrm{R})$ & 1226 & 1394 \\
11 & Relief ratio $(\mathrm{Rh})$ & 12.92 & 12.55 \\
\hline
\end{tabular}

shows that both the basins are having higher drainage density towards downstream, it is mainly due to the availability of alluvium which has more erosion potential.

\section{Stream frequency (Sf)}

Horton (1932) introduced stream frequency (Sf) as a total number of streams from all stream orders per unit area. Sf values for Vaitarna and Ulhas basins are 0.82 and 0.80 , respectively. Sf depends on the lithology of the basin, and it affects the drainage texture. There is a positive correlation between stream frequency and drainage density that indicates as the stream frequency increases, drainage density also increases.

\section{Drainage texture $(\mathrm{T})$}

Drainage texture $(\mathrm{T})$ varies depending on several numbers of factors such as climate, lithology, relief, infiltration capacity, vegetation covers and the stage of drainage development (Smith 1950). Massive, resistant rock shows coarse drainage texture and, at the same time area underlain by soft or weak rock, shows fine drainage texture. The drainage texture mainly depends upon climate and vegetation of an area (Dornkamp and King 1971). In a different climatic region such as the arid or semi-arid area where sparse vegetation found, the drainage texture will be finer compared to the humid climatic region having dense vegetation. Drainage texture is simply the product of drainage density (Dd) and stream frequency $(\mathrm{Sf})$. Both the Vaitarna $(T=0.91)$ and Ulhas $(T=0.85)$ basins exhibit very coarse drainage texture.
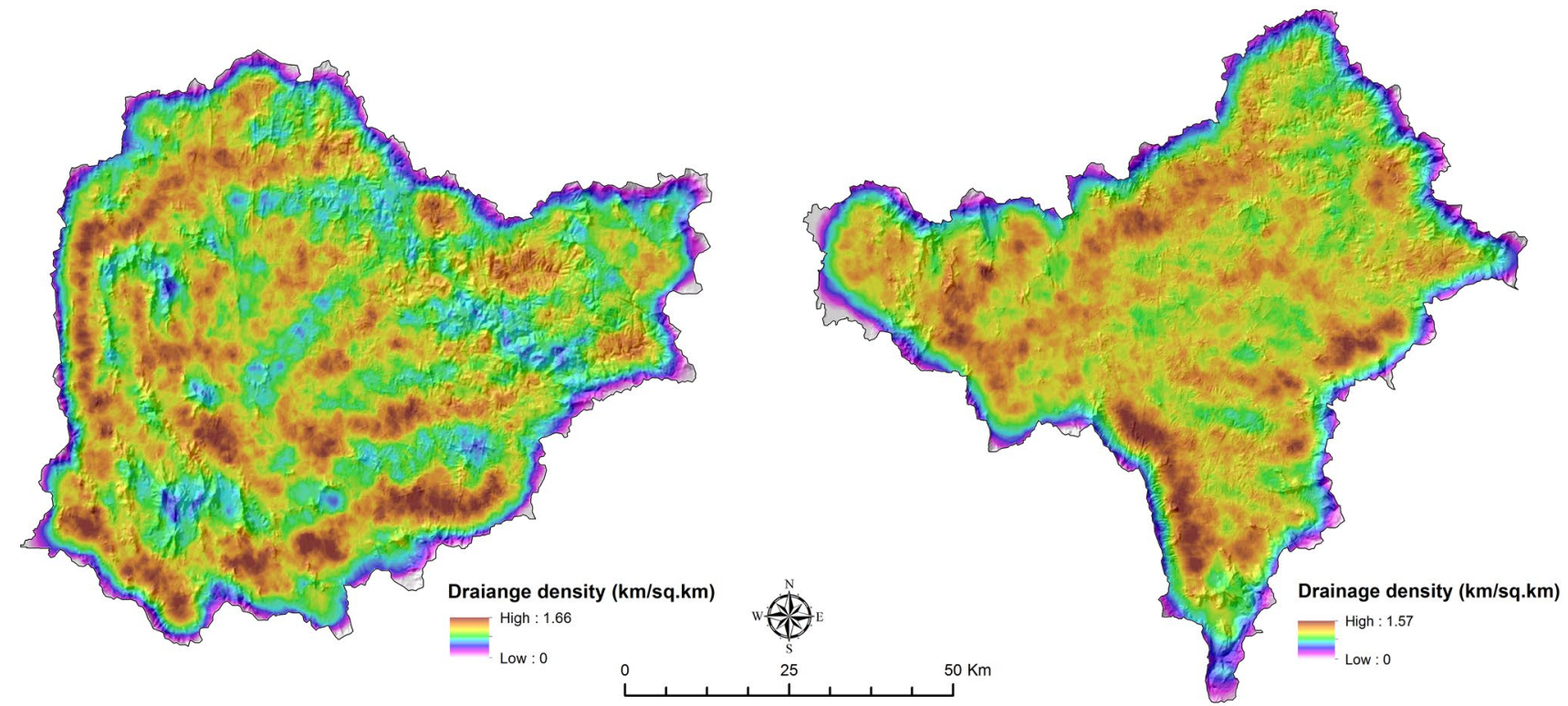

Fig. 5 Drainage density map of Vaitarna and Ulhas basins 


\section{Circularity ratio $(\mathbf{R c})$}

Strahler (1964) demonstrated circularity ratio (Rc) as the ratio of basin area to the area of a circle having the same perimeter of the drainage basin. $R c$ value near to 1 indicates the circular shape of the basin and similar infiltration rate over the basin area. Lower values of $R c$ represent youth stage of basin development where the surface water flow takes comparatively lesser time to reach the basin outlet. $R c$ values of Vaitarna and Ulhas are 0.38 and 0.24 , respectively. Moderate values of $R c$ for both basins indicate mature topography and Ulhas basin is comparatively elongated than Vaitarna.

\section{Elongation ratio $(R e)$}

Elongation ratio $(R e)$ is the ratio between the diameter of a circle having the same area as the basin and total length of the basin (Schumm 1956). Re value will be 1 for a perfect circular basin. As $R e$ decreases, river basin becomes more elongated. Table 4 represents classifications of required $R e$ values for different basin shapes. Both the Vaitarna $(R e=0.73)$ and Ulhas $(R e=0.70)$ basins are showing high elongation ratio, indicating semicircular basin shapes over the study area.

\section{Form factor (Ff)}

Form factor $(\mathrm{Ff})$ can be defined as the ratio between total drainage area and the square of the basin length. Horton (1945) defined this parameter to predict flow intensity of a basin of a defined area. Smaller values of the $F f$ indicates more elongated basin with lower peak flow for a longer duration. More the value of $F f$, more circular the basin with the potential of flash flood due to higher peak flow for a shorter duration. $F f$ values for Vaitarna and Ulhas are 0.42 and 0.38 , respectively. $F f$ values of these basins indicate the semicircular shape of basins with moderate peak flow for shorter time duration.

\section{Relief}

Basin relief is an important geomorphic factor to understand the erosional and mass movement processes in the

Table 4 Elongation ratio (Re) classification for different basin shapes basin area. Basin relief can be defined as the difference between highest elevation and the lowest elevation within the basin. Very high relief of a basin shows steep slopes where hillslope processes predominate and low relief basins are comparatively flat regions having more dominance of in situ weathering processes. Figure 6 shows spatial variation of elevation over the study area. Relief of Vaitarna and Ulhas are 1226 and $1394 \mathrm{~m}$, respectively. Very high relief of these basins indicates steep slope and hillslope are dominating processes along with high-velocity runoff and less infiltration potential over the basin area.

\section{Relief ratio (Rh)}

According to Schumm (1956), relief ratio $(R h)$ is a dimensionless height-length ratio of horizontal distance to the longest extent of the basin to the principal drainage line. $R h$ indicates overall steepness along with the erosional potential of the drainage basin. Both the Vaitarna $(R h=12.92)$ and Ulhas $(R h=12.55)$ basins indicate high values of relief ratio; it implies very steep slope and high-intensity erosional mechanism over the study area.

\section{Slope}

The slope is an important geomorphic aspect which indicates the degree of inclination of a basin concerning the horizontal surface. The understanding slope is essential because it provides valuable information for agriculture, planning, engineering structures, etc., (Sreedevi et al. 2005). Morphoclimatic processes mainly control the slope in areas having different rock types with the various rates of resistance. By using SRTM data sets, slope maps have been prepared in ArcGIS environment. Observation reveals that variation of slope in Vaitarna and Ulhas basins ranges from $0^{\circ}$ to $57^{\circ}$ and $0^{\circ}$ to $69^{\circ}$, respectively (Fig. 7). Higher variation of slope represents steep scarp with rapid runoff and high erosion vulnerability.

\section{Discussion}

The effectiveness of quantitative morphometric analysis of a watershed entirely depends on the interrelationship between various drainage network and relief parameters. The variation in these parameters causes differences in the terrain of a basin (Kale and Rajaguru 1986). In this study, results of all the linear, aerial and relief parameters are attributed on the basis of drainage network and basin relief characteristics.

Vaitarna and Ulhas are classified as 6th and 7th order drainage basins, respectively. Higher stream order indicates greater runoff through the basin outlet due to higher number of tributaries and sub-tributaries (Hajam et al. 2013).

\begin{tabular}{ll}
\hline Range & Shape \\
\hline$<0.5$ & Highly elongated \\
$0.5-0.6$ & Moderately elongated \\
$0.6-0.7$ & Elongated oval \\
$0.7-0.8$ & Semicircular \\
$>0.8$ & Circular \\
\hline
\end{tabular}

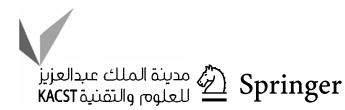




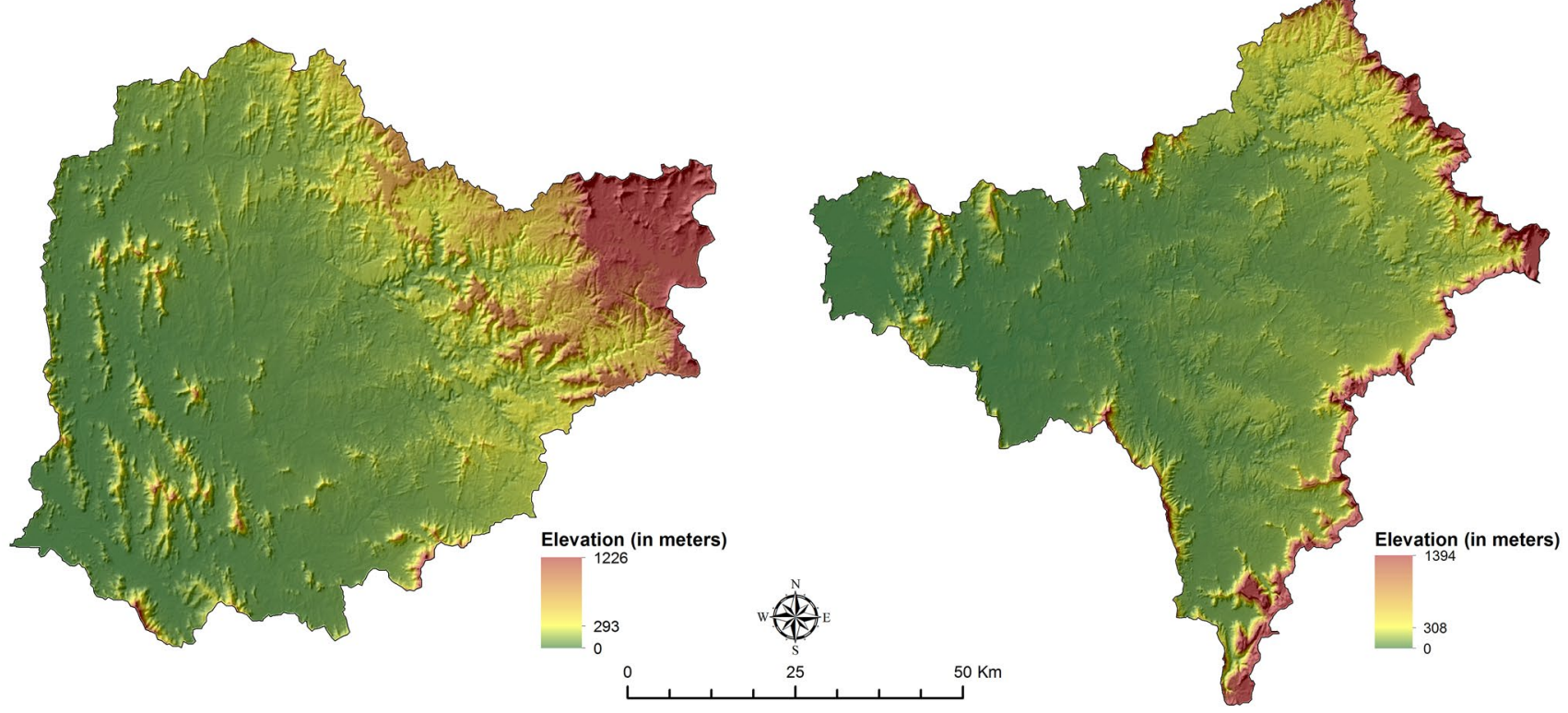

Fig. 6 DEMs are showing a variation of elevation in Vaitarna and Ulhas basin
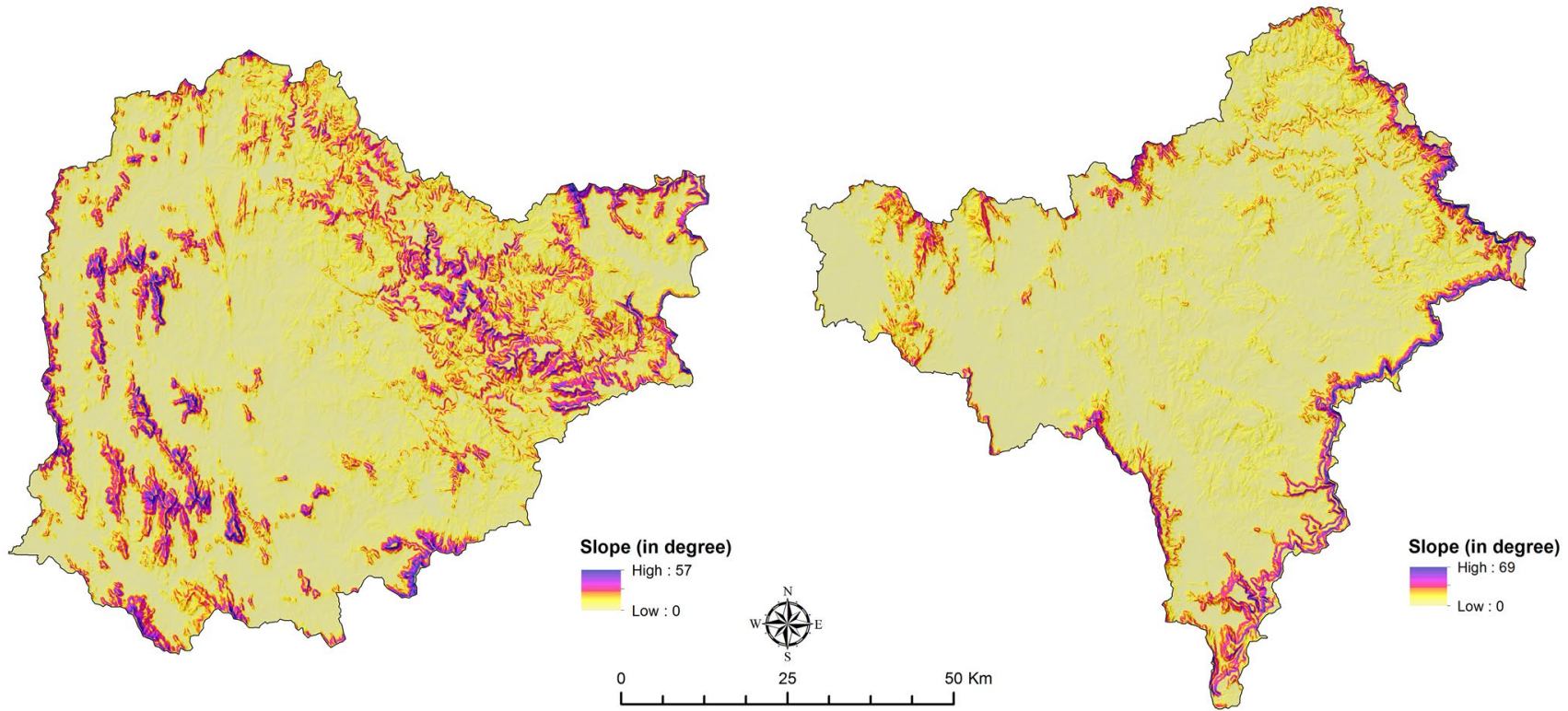

Fig. 7 Slope maps of Vaitarna and Ulhas basins are showing the degree of inclination of land concerning the horizontal ground surface

Figure $4 a, b$ depicts the relationship between stream order with respect to stream number and mean stream length which shows a significant correlation. Horton (1945) demonstrated that when stream order plotted against stream number and stream length, it is shown as a straight line on the semilog scale, which can also be seen in the present study. Strahler (1957) illustrated that significant positive correlation is found between the stream order and the basin area. Similar observations are made in this study where Ulhas basin has much higher basin area compared to the Vaitarna basin. Therefore, the condition of stream order increases as the basin area increases and is fulfilled.

Calculation of bifurcation ratio is one of the fundamental methods to understand the structural control over a drainage basin. Results from previous researches carried out in different locations indicate that the mean bifurcation ratio without geological control varies between 3 and 5 (Vittala et al. 2004; Chopra et al. 2005; Kant et al. 2015; Radwan 
et al. 2017). Vaitarna basin (Rbm- 4.79) shows higher bifurcation ratio as compared to the Ulhas basin (Rbm- 3.94). Hence, Vaitarna river basin is characterised by higher structural control. Observation on the drainage network shows that dendritic drainage pattern is more common in case of lower bifurcation ratio. As the bifurcation ratio increases, the control of structure become higher and river network shows parallel or rectangular drainage pattern. Streams in Vaitarna upstream appears as distinctive parallel drainage network which indicates structural control over the source region but dendritic drainage pattern characterises the Ulhas basin, from source to mouth reflects relatively less control of structure on drainage network.

Aerial morphometric parameters reflect the lithology, climate, tectonics and denudation history of an area. These parameters also control the drainage system and the runoff characteristics. Rao et al. (2010) argued that drainage density depends on the lithology type and structural physiognomies of an area. Region that lies on granitic, gneiss and schist generally shows lower drainage density due to the hard rock lithology. Moreover, drainage density controls the surface runoff which influences the infiltration capacity of an area (Das et al. 2017). In this study, Vaitarna and Ulhas basins show prominent basaltic lithology with a very low drainage density (Vaitarna-1.10; Ulhas-1.06) due to the less erosional mechanism. In the downstream of the both basins, the drainage density increased as a result of the availability of softer alluvium which has a higher erosion potential. Also, lower drainage density indicates good permeability of the sub-surface material in both basins. In the study of Kumar et al. (2015), similar observations were made that region having hard rock lithology is characterised by lower drainage density. Magesh and Chandrasekhar (2014) have shown that range of drainage density in the Western Ghats region indicates similar nature of permeable sub-surface strata. Nag (1998) suggested that drainage density also depends on climatic conditions, relief, infiltration capacity and vegetation cover of an area.

Scholars from different regions clarified that basins having circularity and elongation ratio as 0 are elongated; whereas 1 indicates circular shape (Pandey and Das 2016; Umrikar 2017). Observation on the basin circularity ratio and elongation ratio of the Vaitarna $(0.38,0.73)$ and Ulhas basin $(0.24$, $0.70)$ reflects semicircular shape. Basin shape can reflect the tectonic potential of an area. Bull and McFadden (1977) have shown that basins draining on the tectonically active areas are generally elongated. Hence, it is assumed that Vaitarna and Ulhas basins are tectonically stable. Molin et al. (2004) pointed out that elongation basin shape occurs due to high local relief and steep slope. Despite the circular characteristics, the study area shows steep escarpment and high relief primarily because of the complex character and the location of the Western Ghats escarpment.
Apart from this drainage network and relief parameters, assessment of few factors such as climate, lithology, geomorphology and tectonic settings of an area are imperative to understand the landscape development and evolution, which can be used for future environmental planning. Precipitation over a drainage basin influences the river flow, groundwater storage and the geomorphic character of an area. According to many researchers, Western Ghat has been experienced a periodic uplift since middle Mesozoic until the early Cenozoic period (Radhakrishna 1993; Valdiya and Rajagopalan 2000; Valdiya 2001a, b, 2008; Ramkumar et al. 2017). As a consequence, the uplift of Western Ghat on the path of SW monsoon creates enormous orogenic rainfall over the study area (Gunnel 1998). Rainfall is the primary source of water for all the streams in Vaitarna and Ulhas basins. Although both the basins show very high runoff during the monsoon season, in the non-monsoon period most of the upstream tributaries remain dry. As mentioned before, both the basins show numerous dykes, faults and shears which influence the water to infiltrate, but due to the prominent basaltic lithology over the study area, regardless of the availability of dykes, the study areas do not have a good groundwater potential except those regions having thick alluvium deposit in the downstream.

A thin stretch of Western Ghats escarpment creates very high relief over the study area. Except for this source region, the entire study area shows gentle pediment, scattered hills and coastal plains. These pediment regions are having a dominant mechanism of chemical weathering due to highintensity rainfall in monsoon period and high temperature. Hillslope processes predominate on the upstream of both basins where the Western Ghat escarpment is located. Combined work of all these denudation processes through space and time leads to the study area to evolve into mature to early-old stage of basin development.

\section{Conclusion}

The innovation of remote sensing and GIS technology made geospatial analysis easier than ever. By using DEM, any computational studies for a basin covering a large area can be easily done with high accuracy. These new technologies have replaced the traditional methods of morphometric analysis. The fluvial landscape is a fundamental geomorphic feature can be seen anywhere in this world except high-latitude polar region. Therefore, for any watershed management, the morphometric analysis is an essential study.

The present paper describes the morphometric analysis of Vaitarna and Ulhas river basins. Vaitarna and Ulhas are classified as 6th and 7th order drainage basin, having an area of $3795 \mathrm{~km}^{2}$ and $4733 \mathrm{~km}^{2}$, respectively. The majority of the area in both basins show dendritic drainage pattern. 
Bifurcation ratio of Vaitarna river basin indicates low to moderate structural control, but Ulhas does not show any structural control over the drainage area. Low drainage density observed in both basins mainly due to the hard rock lithological structures which reveal the surface area has very low permeability. Stream frequency and drainage texture are indicating very coarse spacing between streams because of sparse vegetation cover and dry climatic conditions. Circularity ratio, elongation ratio and form factor represent semicircular basin shape for both basins with moderate peak flow. Relief properties of the drainage basins have shown that both basins are having a steep slope and high intensity of erosional mechanism. Overall analysis of the present study indicates mature to early-old stage of drainage development over the study area. The study also relates climate, lithology, geomorphology and tectonic history with respect to the morphometric characteristics. The present study can be directly applied for future planning and management of Vaitarna and Ulhas basins.

Acknowledgement The authors wish to thank Saad A. Al-Jlil (Editor-in-Chief, Applied Water Science) for his valuable suggestions in improving the revised manuscript. Critical review and constructive comments from the anonymous reviewers significantly improved the final paper.

Open Access This article is distributed under the terms of the Creative Commons Attribution 4.0 International License (http://creativeco mmons.org/licenses/by/4.0/), which permits unrestricted use, distribution, and reproduction in any medium, provided you give appropriate credit to the original author(s) and the source, provide a link to the Creative Commons license, and indicate if changes were made.

\section{References}

Boulton AG (1968) Morphometric analysis of river basin characteristics. Water Resource Board, UK

Bull W, McFadden L (1977) Tectonic geomorphology north and south of the Garlock Fault California. In: Doehring DO (ed) Geomorphology in Arid regions. State University of New York, Binghamton, pp 115-138

Chopra R, Dhiman RD, Sharma PK (2005) Morphometric analysis of subwatersheds in Gurdaspur District Punjab using remote sensing and GIS techniques. J Indian Soc Remote Sens 33:531-539. https ://doi.org/10.1007/BF02990738

Clarke JI (1996) Morphometry from maps. Essays in geomorphology. Elsevier Publ. Co., New York, pp 235-274

Costa JE (1987) Hydraulics and basin morphometry of the largest flash floods in the conterminous United States. J Hydrol 93:313-338. https://doi.org/10.1016/0022-1694(87)90102-8

Das S (2017) Signatures of morphotectonic activities in western upland Maharashtra and Konkan region. Unpublished M.Sc. thesis, Savitribai Phule Pune University

Das S, Gupta A, Ghosh S (2017) Exploring groundwater potential zones using MIF technique in semi-arid region: a case study of Hingoli district, Maharashtra. Spat Inf Res 25(6):749-756. https ://doi.org/10.1007/s41324-017-0144-0

Das S, Pardeshi SD, Kulkarni PP, Doke A (2018) Extraction of lineaments from different azimuth angles using geospatial techniques: a case study of Pravara basin, Maharashtra, India. Arab J Geosci 11(8):160. https://doi.org/10.1007/s12517-018-3522-6

Das S, Pardeshi SD (2018) Comparative analysis of lineaments extracted from Cartosat, SRTM and ASTER DEM: a study based on four watersheds in Konkan region, India. Spat Inf Res 26(1):47-57

Deng Y (2007) New trends in digital terrain analysis: landform definition, representation and classifcation. Prog Phys Geogr 31(4):405-419. https://doi.org/10.1177/0309133307081291

Dietrich WE, Wilson CJ, Montgomery DR, McKean J (1993) Analysis of erosion thresholds, channel networks, and landscape morphology, using a digital terrain model. J Geol 101(2):259-278. https://doi.org/10.1086/648220

Doke A, Pardeshi SD, Pardeshi SS, Das S (2018) Identification of morphogenetic regions and respective geomorphic processes: a GIS approach. Arab J Geosci 11(2):20. https://doi.org/10.1007/ s12517-017-3358-5

Dornkamp JC, King CAM (1971) Numerical analyses in geomorphology, an introduction. St. Martins Press, New York, p 372

Gardiner V (1975) Drainage basin morphometry. Br Geomorphol Res Group Tech Bull 14:48

Goodbred SL Jr (2003) Response of the Ganges dispersal system to climate change: a source-to-sink view science the last interstade. Sediment Geol 162:83-104. https://doi.org/10.1016/ S0037-0738(03)00217-3

Gunnel Y (1998) The interaction between geological structure and global tectonics in multistoreyed landscape development: a denudation chronology of the South Indian shield. Basin Res 10:281-310. https://doi.org/10.1046/j.1365-2117.1998.00072.x

Hadley RF, Schumm SA (1961) Sediment sources and drainage basin characteristics in upper Cheyenne River Basin. US Geol Survey Water-Supply Paper 1531-B, p 198

Hajam RA, Hamid A, Bhat S (2013) Application of morphometric analysis for geo-hydrological studies using geo-spatial technology: a case study of Vishav drainage basin. Hydrol Curr Res 4:12. https://doi.org/10.4172/2157-7587.1000157

Horton RE (1932) Drainage basin characteristics. Trans Am Geophys Union 13:350-361

Horton RE (1945) Erosional development of streams and their drainage basins: hydrophysical approach to quantitative morphology. Bull Geol Soc Am 56:275-370. https://doi.org/10.1130/00167606(1945)56\%5b275:EDOSAT\%5d2.0.CO;2

Jacques PD, Salvador ED, Machado R, Grohmann CH, Nummer AR (2014) Application of morphometry in neotectonic studies at the eastern edge of the Parana Basin Santa Catarina State Brazil. Geomorphology 213:13-23. https://doi.org/10.1016/j.geomo rph.2013.12.037

Kale VS, Rajaguru SN (1986) A parametric approach to terrain analysis and geomorphic regionalization of Pravara river basin (Maharashtra). J Geol Soc India 27:369-378

Kale VS, Shejwalkar N (2007) Western Ghat escarpment evolution in the Deccan Basalt Province: geomorphic observations based on DEM analysis. J Geol Soc India 70:459-473

Kant S, Meshram S, Dohare R, Singh S (2015) Morphometric analysis of Sonar sub-basin using SRTM data and geographical information system (GIS). Afr J Agric Res 10:1401-1406. https://doi. org/10.5897/AJAR2013.7907

Kumar A, Samuel SK, Vyas V (2015) Morphometric analysis of six sub-watersheds in the central zone of Narmada river. Arab J Geosci 8:5685-5712. https://doi.org/10.1007/s12517-014-1655-9

Lindsay JB, Evans MG (2008) The influence of elevation error on the morphometrics of channel networks extracted from DEMs and the implications for hydrological modelling. Hydrol Process 22(11):1588-1603. https://doi.org/10.1002/hyp.6728 
Lindsay JB, Creed IF, Beall FD (2004) Drainage basin morphometrics for depressional landscapes. Water Resour Res 40(9):W09307. https://doi.org/10.1029/2004WR003322

Magesh NS, Chandrasekhar N (2014) GIS model-based morphometric evaluation of Tamiraparani sub basin, Tirunelveli district, Tamil Nadu, India. Arab J Geosci 7:131-141. https://doi.org/10.1007/ s12517-012-0742-Z

Magesh NS, Jitheshlal KV, Chandrasekar N, Jini KV (2012) GIS based morphometric evaluation of Chimmini and Mupily watersheds, parts of Western Ghats, Thrissur District, Kerala. India. Earth Sci Inform 5(2):111-121. https://doi.org/10.1007/s12145-012-0101-3

Mesa LM (2006) Morphometric analysis of a subtropical Andean basin (Tucuman, Argentina). Environ Geol 50(8):1235-1242. https:// doi.org/10.1007/s00254-006-0297-y

Miller VC (1953) A quantitative geomorphologic study of drainage basin characteristics in the Clinch Mountain area, Virginia and Tennessee. Project NR 389042, Tech Report 3. Columbia University, Department of Geology, ONR Geography Branch, New York

Molin P, Pazzagila FJ, Dramis F (2004) Geomorphic expression of active tectonics in a rapidly-deforming fore-arc, Sila Massif, Calabria, Southern Italy. Am J Sci 304:559-589. https://doi. org/10.2475/ajs.304.7.559

Moussa R (2003) On morphometric properties of basin, scale effects and hydrological response. Hydrol Processes 17:33-58. https:// doi.org/10.1002/hyp.1114

Nag SK (1998) Morphometric analysis using remote sensing techniques in the Chaka Sub-basin, Purulia District, West Bengal. J Indian Soc Remote Sens 20(12):69-76. https://doi.org/10.1007/ BF03007341

Nag SK, Chakraborty S (2003) Influence of rock types and structures in the development of drainage network in hard rock area. J Indian Soc Remote Sens 31(1):25-35. https://doi.org/10.1007/BF030 30749

Nautiyal MD (1994) Morphometric analysis of a drainage basin, district Dehradun Uttar Pradesh. J Indian Soc Remote Sens 22(4):251-261. https://doi.org/10.1007/BF02990738

Pandey PK, Das SS (2016) Morphometric analysis of Usri river basin, Chhotanagpur Plateau, India, using remote sensing and GIS. Arab J Geosci 9:240. https://doi.org/10.1007/s12517-015-2287-4

Radhakrishna BP (1993) Neogene uplift and geomorphic rejuvenation of Indian Peninsula. Curr Sci 64:787-793

Radwan F, Alazba AA, Mossad A (2017) Watershed morphometric analysis of Wadi Basin Dam catchment area using integrated GISbased approach. Arab J Geosci 10:256. https://doi.org/10.1007/ s12517-017-3046-5

Ramkumar M, Menier D, Mathew MJ, Santosh M, Siddiqui NA (2017) Early Cenozoic rapid flight enigma of the Indian subcontinent resolved: the roles of topographic top loading and subcrustal erosion. Geosci Front 8(1):15-23. https://doi.org/10.1016/j. gsf.2016.05.004

Rao NK, Latha SP, Kumar AP, Krishna HM (2010) Morphometric analysis of Gostani River basin in Andhra Pradesh State, India using spatial information technology. Int J Geomagn Geosci $1: 179-187$

Schumm SA (1956) Evolution of drainage systems and slopes in bed lands at Perth Amboy, New Jersey. Bull Geol Soc Am 67:597646. https://doi.org/10.1130/0016-7606(1956)67\%5b597:EODSA $\mathrm{S} \% 5 \mathrm{~d} 2.0 . \mathrm{CO} ; 2$
Schumm SA (1963) Sinuosity of alluvial rivers in the great plains. Bull Geol Soc Am 74:1089-1100. https://doi.org/10.1130/00167606(1963)74\%5b1089:SOAROT\%5d2.0.CO;2

Smith KG (1950) Standards for grading texture of erosional topography. Am J Sci 248:655-668. https://doi.org/10.2475/ajs.248.9.655

Sreedevi PD, Subrahmanyam K, Shakeel A (2005) The significance of morphometric analysis for obtaining groundwater potential zones in a structurally controlled terrain. Env Geol 47(3):412-420. https ://doi.org/10.1007/s00254-004-1166-1

Strahler AN (1952) Dynamics basis of geomorphology. Bull Geol Soc Am 63:923-938. https://doi.org/10.1130/00167606(1952)63\%5b923:DBOG\%5d2.0.CO;2

Strahler AN (1957) Quantitative analysis of watershed geomorphology. Trans Am Geophys Union 38:913-920. https://doi.org/10.1029/ TR038i006p00913

Strahler AN (1964) Quantitative geomorphology of drainage basins and channel networks. In: Chow VT (ed) Hand book of applied hydrology. McGraw Hill Book Company, New York

Subrahmanya KR (1987) Evolution of the Western Ghats, India- a simple model. J Geol Soc India 29:446-449

Umrikar BN (2017) Morphometric analysis of Andhale watershed, Taluka Mulshi, District Pune, India. Appl Water Sci 7(5):22312243. https://doi.org/10.1007/s13201-016-0390-7

Valdiya KS (2001a) River response to continuing movements and the scarp development in central Sahyadri and adjoining coastal belt. J Geol Soc India 57:13-30

Valdiya KS (2001b) Tectonic resurgence of the Mysore plateau and surrounding regions in cratonic Southern India. Curr Sci 81:1068-1089

Valdiya KS (2008) Sinking of ancient Talakad temples on the Kaveri bank, Mysore Plateau, Karnataka. Curr Sci 95:1675-1676

Valdiya KS, Rajagopalan G (2000) Large paleolakes in Kaveri Basin in Mysore Plateau: late quaternary fault reactivation. Curr Sci 78:1138-1142

Verstappen H (1983) The applied geomorphology. International Institute for Aerial Survey and Earth Science (I.T.C), Enschede

Vittala S, Govindaiah S, Honne GH (2004) Morphometric analysis of sub-watersheds in the Pavagada area of Tumkur district, South India using remote sensing and GIS techniques. J Ind Soc Rem Sen 32(4):351-362. https://doi.org/10.1007/BF03030860

Widdowson M (1997) Tertiary palaeosurfaces of the SW Deccan, Western India: Implication for passive margin uplift. In: Paleosurfaces: recognition, reconstruction and palaeoenvironment interpretation. Geological Society Special Publication, London, no. 120 , pp 221-248

Wilson JP, Aggett G, Deng Y, Lam CS (2008) Water in the landscape: a review of contemporary flow routing algorithms. In: Zhou Q, Lees B, Tang G (eds) Advances in digital terrain analysis, vol 3. Lecture notes in geoinformation and cartography series. Springer, Berlin, pp 213-236

Zhang Y (2005) Global tectonics and climatic control of mean elevation of continents and Phanerozoic sea level change. Earth Planet Sci Lett 237:524-531. https://doi.org/10.1016/j.epsl.2005.07.015

Publisher's Note Springer Nature remains neutral with regard to jurisdictional claims in published maps and institutional affiliations. 